\title{
RESPON TANAMAN DAHLIA (Dahlia pinnata) PADA BERBAGAI MACAM MEDIA TANAM DAN PUPUK ORGANIK CAIR
}

\author{
Libria Widiastuti $^{1)}$, Tri Pamujiasih ${ }^{2)}$ \\ 1) Fakultas Teknik, Sains, dan Pertanian, Program Studi Agroteknologi, Universitas Islam Batik Surakarta, Jl. \\ KH.Agus Salim No.10 Surakarta, Telp (0271) 714750, email:olibwidiahoki@gmail.com \\ ${ }^{2)}$ Fakultas Teknik, Sains, dan Pertanian, Program Studi Agroteknologi, Universitas Islam Batik Surakarta, Jl. \\ KH.AgusSalim No.10 Surakarta, Telp (0271) 714750; Email:tripamujiasih18@gmail.com
}

\begin{abstract}
Abstrak
Tujuan dalam penelitian ini adalah : (1) untuk mengetahui pengaruh macam media tanam yang baik untuk pertumbuhan dan kualitas bunga pada tanaman dahlia. (2) untuk mengetahui pengaruh macam pupuk organik cair yang baik untuk pertumbuhan dan kualitas bunga pada tanaman dahlia. (3) untuk mengetahui interaksi macam media tanam dan macam pupuk organik cair terhadap pertumbuhan dan kualitas bunga pada tanaman dahlia. Penelitian ini telah dilaksanakan pada bulan Juli sampai Oktober 2019 di Kudu Baki Sukoharjo Jawa Tengah dengan ketinggian tempat 100 meter di atas permukaan laut. Percobaan diatur dalam Rancangan Acak Lengkap (RAL), yang terdiri dari dua faktor dan tiga ulangan. Macam Media Tanam (M) terdiri dari 4 taraf, yaitu : top soil, arang sekam, humus daun bambu, dan pakis. Macam Pupuk Organik Cair (P) terdiri dari 3 taraf, yaitu : DI Grow, GDM, dan Grow more. Hasil penelitian menunjukkan bahwa perlakuan pupuk organik DI Grow dan media tanam arang sekam menunjukkan hasil tertinggi secara nyata terhadap semua parameter pengamatan yaitu tinggi tanaman, luas daun, saat munculnya bunga, diameter bunga, diameter umbi dan umur panen. Perlakuan pupuk Growmore dan media tanam top soil menunjukkan hasil terendah secara nyata terhadap semua parameter pengamatan yaitu tinggi tanaman, luas daun, saat munculnya bunga, umur panen, diameter bunga dan umur pajang tanaman. Tidak ada interaksi antara perlakuan macam media tanam dan macam pupuk organik cair pada semua parameter pengamatan.
\end{abstract}

Kata kunci: bunga, dahlia, media tanam, pupuk organik cair

\begin{abstract}
The objectives in this study are: (1) to determine the effect of various types of planting media that are good for growth and quality of flowers on dahlia plants. (2) to determine the effect of various types of liquid organic fertilizer which is good for growth and flower quality in dahlia plants. (3) to determine the interaction of various types of planting media and liquid organic fertilizer types on the growth and quality of flowers in seruni plants. This research was conducted from July to October 2019 in Kudu BakiSukoharjo, Central Java, with a height of 100 meters above sea level. The experiments were arranged in a Completely Randomized Design (CRD), which consisted of two factors and three replications. Kinds of Planting Media (M) consist of 4 levels, namely: top soil, husk charcoal, bamboo leaf humus, and fern. Liquid Organic Fertilizer $(P)$ consists of 3 levels, namely: IN Grow, GDM, and Grow more. The results showed that the treatment of organic fertilizer in Grow and planting media of rice husk showed the highest results significantly for all observations, namely plant height, leaf area, flower appearance, flower diameter, tuber diameter and harvest age. Growmore fertilizer treatment and top soil planting media showed the lowest results significantly for all observed parameters, namely plant height, leaf area, flower appearance, harvest age, flower diameter and plant shelf life. There was no interaction between the treatment types of the planting media and the types of liquid organic fertilizer on all observational parameters.
\end{abstract}

Keywords: dahlias, flowers, growing media, liquid organic fertilizer 


\section{PENDAHULUAN}

Tanaman dahlia di Indonesia sampai saat ini baru dibudidayakan untuk diambil bunganya sebagai tanaman hias. Bunga dahlia dimanfaatkan sebagai bunga potong sedangkan umbinya yang masih memiliki batang digunakan sebagai bibit sementara umbi yang tidak memiliki batang terbuang menjadi limbah. Saat ini diketahui bahwa umbi dahlia merupakan sumber karbohidrat yang berupa inulin. Umbi dahlia kering mengandung inulin sebanyak $65-75 \%$ dari total karbohidrat yang ada di dalamnya. Besarnya jumlah inulin di dalam umbi dahlia menjadi potensi yang besar untuk diolah menjadi gula fruktosa dan frukto oligosakarida. Fruktosa adalah bahan pemanis alami yang memiliki kadar kemanisan 2,5 kali lipat dari sukrosa (Haryani, et.al, 2013).

Umbi bunga dahlia belum begitu banyak diminati masyarakat untuk dijadikan salah satu bahan olahan pangan. pengubahan bentuk umbi dahlia menjadi berbentuk tepung dapat mempermudah pemanfaatan umbi dahlia untuk penggunaan dalam pengolahan sebagai bahan setengah jadi selain itu perubahan bentuk menjadi tepung juga dapat memperbaiki daya simpannya sehingga umur simpannya dapat lebih lama.

Berdasarkan uji fitokimia yang telah dilakukan Suryadi (2007), diketahui bahwa umbi tanaman dahlia berbunga merah mengandung golongan flavonoid, fenolik, dan saponin. Menurut Iskandar,dkk (2014) umbi dahlia dari bunga berwarna merah yang ditanam pada tanah inceptisols (Sukabumi) memiliki kadar inulin tertinggi dari pada bunga dahlia yang berwarna ungu, kuning dan putih. Namun perbedaan sifat fisikokimia umbi yang telah dijadikan tepung dari berbagai warna bunga dahlia belum dilakukan pengujian.

Pupuk organik merupakan pupuk yang terbuat dari bahan organik, yang diperbaharui dan dirombak oleh bakteri tanah menjadi unsur-unsur yang dapat digunakan oleh tanaman tanpa mencemari tanah dan air (Sutedjo, 2010). Salah satunya dengan menggunakan sisa-sisa tanaman yang telah didekomposisi menjadi kompos atau diekstraksi menjadi pupuk cair organik seperti pupuk organik cair D.IGrow.

D.I Grow adalah pupuk organik cair berkualitas tinggi yang terbuat dari rumput laut acadian seaweed dari jenis Ascophylumnodosum (sejenis alga coklat) yang diperoleh dari Lautan Atlantik Utara, diproses dengan nano technology (USA Formula Technology). Gardner et al. (1991) menambahkan bahwa pertumbuhan dan hasil suatu tanaman dipengaruhi oleh keadaan lingkungan tumbuhnya. Salah satu faktor lingkungan yang penting adalah ketersediaan unsur hara dan pengendalian organisme pengganggu tanaman.

\section{BAHAN DAN METODE}

\section{Bahan}

Benih dahlia; top soil; arang sekam; humus daun bambu; pakis; Rootone F; furadan 3G; akodan 350 EC; dithane M-45.

\section{Alat}

Cangkul; cetok; ember; gembor; hand sprayer; polibag; kertas karton; pisau; gunting; penggaris; alat tulis; timbangan digital; gelas ukur kapasitas 10 ml; label.

\section{Metode}

Rancangan Penelitian diatur dalam Rancangan Acak Lengkap (RAL),yang terdiri dari dua faktor dan tiga ulangan. Macam Media Tanam (M) terdiri dari 4 taraf, yaitu : Top soil, Arang sekam, Humus daun bambu, dan Pakis. Macam Pupuk Organik Cair (P) terdiri dari 3 taraf, yaitu : DI Grow, GDM, dan Grow more.

\section{Pesemaian dan Pindah Tanam}

Benih berasal dari tanaman dahlia yang sehat berumur 5 bulan. Benih langsung disemai di atas persemaian yang telah 
disiapkan. Media semai dibuat dari campuran humus, pupuk kandang sapi dan tanah yang subur dengan perbandingan $1: 1: 1$. Benih disebarkan merata di atas tray semai dan ditutup tipis-tipis dengan tanah. Pada musim kemarau tray ditutup dengan daun pisang yang telah dicuci yang bersih agar kelembaban terjaga. Tray semai perlu diberi naungan bila persemaian dilakukan pada musim hujan. Naungan berupa plastik transparan setinggi $80 \mathrm{~cm}$ di sisi timur dan $60 \mathrm{~cm}$ di sisi barat.

Setelah benih berkecambah dan berdaun dua helai, penutup (daun pisang/karung goni) dibuka. Bibit dipelihara dipersemaian sampai berdaun sempurna 2 helai bibit dipindah tanamkan ke polybag transparan $18 \times 15 \mathrm{~cm}$ berisi campuran sekam dan pupuk kandang sapi (6:1). Setelah tanaman berdaun 6helai, dilakukan pindah tanam kedua ke dalam polybag transparan $30 \times 20 \mathrm{~cm}$ berisi media yang sama. Di dalam polybag ini tanaman dipelihara sampai berbunga selama 2 bulan.

\section{Pemeliharaan}

\section{a. Penyiraman}

Penyiraman setiap pagi dan sore hari secara manual hingga tanah cukup basah.

\section{b. Pemupukan}

Pemupukan dilakukan setiap 10 hari sekali dengan pupuk sesuai perlakuan.

\section{c. Proteksi tanaman}

1) Insektisida Akodan 350 EC sebanyak 1 $\mathrm{ml} /$ liter disemprotkan satu minggu setelah tanam sampai menjelang panen dengan selang waktu satu minggu.

2) Fungisida Dithane $M-45$ dengan dosis 2 g/liter disemprotkan satu minggu setelah tanam dengan selang waktu satu minggu.

\section{d. Penyiangan}

Dilaksanakan mulai 2 minggu setelah tanam dan diulang secara periodik dengan interval 1 minggu sampai menjelang panen. Cara penyiangan dengan membersihkan rumput dan jenis gulma lain yang tumbuh disekitar tanaman.

\section{e. Panen}

1) Kriteria Panen : bunga tiga bulan setelah tanam, bunga pertama dapat dipetik 2 kali seminggu sampai 4 bulan kemudian. Bunga yang siap dipetik telah mekar penuh dengan diameter $10 \mathrm{~cm}$.

2) Cara Panen : bunga dahlia dipetik dengan cara memotong tangkai bunga sepanjang $20 \mathrm{~cm}$ dari dasar bunga. Bunga dahlia semi kaktus dipanen dengan cara memotong tangkai bunga sepanjang $50 \mathrm{~cm}$ dari dasar bunga.

\section{Teknik Pengumpulan Data}

Data dikumpulkan dari lima tanaman sampel dan lima tanaman korban dari setiap perlakuan, sehingga setiap perlakuan terdapat 10 tanaman.

\section{Analisis Data}

Semua data yang diperoleh dianalisis dengan menggunakan analisis varian. Apabila ada beda nyata antar perlakuan maka hasil analisis diuji lanjut dengan uji jarak berganda Duncan 5\%. Data yang menunjukkan kualitas tanaman dianalisis regresi.

\section{HASIL DAN PEMBAHASAN}

Selama di pembibitan, benih dahlia tumbuh dengan baik dan seluruhnya dapat berakar dua minggu setelah tanam. Selama penelitian berlangsung tanaman dahlia tidak memperlihatkan gejala penyakit secara serius, namun demikian pencegahan dilakukan dengan cara penyemprotan tanaman dengan Dithane M45 dengan dosis 2g/liter dan Akodan 125 EC dengan dosis $1 \mathrm{ml} /$ liter pada bagian bawah daun tiap satu minggu.

Hasil analisis varian menunjukkan tidak ada interaksi antara perlakuan media tanam dan pupuk organik cair pada semua parameter. 
Widiastuti \& Pamujiasih. 2019

Tabel 4. Tinggi tanaman (cm) dan Luas Daun $\left(\mathrm{cm}^{2}\right)$

\begin{tabular}{ccc}
\hline & $\begin{array}{c}\text { Tinggi } \\
\text { Tanaman }\end{array}$ & Luas Daun \\
\hline P.O.C & & \\
DI Grow & $89,16 \mathrm{a}$ & $59,19 \mathrm{a}$ \\
GDM & $82,98 \mathrm{ab}$ & $56,18 \mathrm{a}$ \\
Growmore & $76,20 \mathrm{~b}$ & $50,68 \mathrm{a}$ \\
\hline Media Tanam & & \\
Top Soil & $88,76 \mathrm{p}$ & $54,38 \mathrm{p}$ \\
Arang Sekam & $94,88 \mathrm{q}$ & $58,11 \mathrm{q}$ \\
Humus daun & $89,05 \mathrm{pq}$ & $54,67 \mathrm{pq}$ \\
bambu & $89,07 \mathrm{pq}$ & $54,69 \mathrm{pq}$ \\
Pakis & & $(-)$ \\
\hline Interaksi & $(-)$ & \\
\hline Keterangan & Angka & $\mathrm{dlkuth}$ \\
\hline
\end{tabular}

Keterangan : Angka diikuti huruf sama menunjukkan tidak berbeda nyata pada uji, Duncan $5 \%$

Tanda (+) menunjukkan ada interaksi antar perlakuan.

Tinggi tanaman ini nantinya akan menentukan panjang tangkai bunga potong dahlia, semakin tinggi tanaman maka semakin panjang tangkai bunga yang dihasilkan. Prasetya (2009) menjelaskan bahwa unsur nitrogen bermanfaat untuk pertumbuhan vegetatif tanaman yaitu pembentukan sel-sel baru seperti daun, cabang, dan mengganti sel-sel yang rusak. Setyamidjaja (1986) mengemukakan bahwa apabila tanaman kekurangan unsur $\mathrm{N}$ tanaman akan memperlihatkan pertumbuhan yang kerdil. Selain faktor diatas adanya interaksi berbagai faktor internal pertumbuhan (yaitu atas kendali genetik) dan unsur-unsur iklim, tanah dan biologis juga berpengaruh terhadap tidak terdapatnya pertambahan tinggi tanaman. Hal ini disebabkan bahwa tinggi tanaman dahlia juga dipengaruhi oleh lingkungan meliputi: cahaya, suhu udara, kelembapan udara, curah hujan dan ketinggian tempat. Sesuai dengan pendapat Gardner, et.al. (1991) menyatakan bahwa tinggi tanaman lebih dipengaruhi oleh faktor lingkungan seperti cahaya, iklim dan CO2.
Pada pengamatan terlihat proses pertumbuhan dan perkembangan pada tanaman dahlia, hal ini susuai menurut Agustina (2016) menyatakan morfogenesis adalah proses pertumbuhan dan perkembangan bentuk, diferensiasi suatu organisme.Embrio yang terbentuk di dalam biji memiliki kotiledon dan akar serta tunas rudimeter. Sesudah berkecambah, akar dan tunas rudimeter tersebut akan berkembang membentuk sistem akar dan tunas tumbuhan. Proses ini yang dinamakan morfogenesis. Pertumbuhan pertambahan tinggi yang baik bagi tanaman dahlia pada umur 9MST adalah konsentrasi $15 \mathrm{ml} / \mathrm{l}$ air (K3), hal ini karena terdapat unsur hara makro pada pupuk organik cair yang mendukung pertumbuhan tinggi tanaman.

Sesuai dengan pendapat Campbell, (2012) menyatakan pertumbuhan tinggi tanaman dapat didukung pula oleh ketersediaan makronutrien lainnya, seperti karbon, oksigen, hidrogen, nitrogen, fosfor, kalium, kalsium, dan sulfur yang dibutuhkan untuk siklus hidup tanaman dan menghasilkan generasi yanglain.

Daun merupakan organ tanaman tempat berlangsungnya proses fotosintesis, bila luas daun meningkat, asimilat yang dihasilkan akan lebih banyak. Asimilat tersebut digunakan untuk pembentukan daun, sehingga jumlah daun yang dibentuk lebih banyak.

Luas daun dapat dijadikan ukuran status air di dalam tanah. Pada kondisi kekurangan air akan terjadi penurunan dalam pembentukan dan perluasan daun. Lengas yang diserap tanaman digunakan untuk pertumbuhan dan perkembangan sel sebagai akibat kenaikan turgor pada sel-sel tersebut. Apabila lengas yang diserap tanaman berkurang akan menyebabkan tekanan turgor berkurang dan akibatnya pembesaran sel daun akan berkurang yang berdampak pada penghambatan pertumbuhan daun. 
Widiastuti \& Pamujiasih. 2019

Agrisaintifika

Jurnal Ilmu-Ilmu Pertanian

Vol. 3, No. 2, 2019

Tabel 5. Saat munculnya bunga (hari) dan Diameter bunga $\left(\mathrm{cm}^{2}\right)$

\begin{tabular}{ccc}
\hline Perlakuan & $\begin{array}{c}\text { Saat } \\
\text { munculny } \\
\text { a bunga }\end{array}$ & $\begin{array}{c}\text { Diameter } \\
\text { Bunga }\end{array}$ \\
\hline
\end{tabular}

\begin{tabular}{ccc}
\hline P.O.C & & \\
& & \\
DI Grow & $50,92 \mathrm{a}$ & $5,52 \mathrm{~b}$ \\
GDM & $64,88 \mathrm{~b}$ & $5,67 \mathrm{a}$ \\
Growmore & $67,79 \mathrm{~b}$ & $4,05 \mathrm{ab}$ \\
\hline Media Tanam & & \\
Top Soil & $60,08 \mathrm{q}$ & $3,34 \mathrm{~b}$ \\
& & $4,56 \mathrm{a}$ \\
Arang Sekam & $54,08 \mathrm{p}$ & $3,53 \mathrm{~b}$ \\
Humus daun & $55,91 \mathrm{q}$ & \\
bambu & & $3,54 \mathrm{~b}$ \\
Pakis & $54,72 \mathrm{q}$ & $(-)$ \\
\hline Interaksi & $(-)$ & sikuti
\end{tabular}

Keterangan : Angka diikuti huruf sama menunjukkan tidak berbeda nyata pada uji, Duncan 5\%.

Tanda (+) menunjukkan ada interaksi antar perlakuan.

Pada tabel 5 dapat dilihat bahwa tanaman pada perlakuan pupuk organik membutuhkan hari tidak terpaut jauh untuk muncul bunga pertama, hal ini disebabkan karena semakin tersedianya unsur hara yang dibutuhkan tanaman maka akan semakin banyak yang dimanfaatkan oleh tanaman untuk pertumbuhannya, sehingga akan terjadi peningkatan proses metabolisme, utamanya peningkatan fotosintesis.

Pada percobaan ini menggunakan penambahan pupuk organik cair dimana pupuk ini mengandung unsur makro dan mikro yang dibutuhkan oleh pertumbuhan tanaman serta juga mengandung gibberellin.

Zat pengatur tumbuh gibberellin merupakan zat yang dapat memacu pertumbuhan bunga pada tanaman yang dengan dosis yang sama pada setiap tanaman. Sehingga hal ini diduga membuat bunga muncul pertama kali serentak pada setiap komposisi media tanam yang di cobakan, karena kandungan unsur hara yang terkandung pada setiap komposisi media tanam yang dicobakan hampir sama dan dengan penambahan pupuk yang sama pada setiap tanaman serta didukung oleh kondisi lingkungan yang mendukung untuk pertumbuhan dan pembungaan tanaman dahlia.

Tabel 6. Diameter Umbi $\left(\mathrm{cm}^{3}\right)$ dan Umur Panen (hari)

\begin{tabular}{ccc}
\hline Perlakuan & $\begin{array}{c}\text { Diameter } \\
\text { Umbi }\end{array}$ & $\begin{array}{c}\text { Umur } \\
\text { Panen }\end{array}$ \\
\hline P.O.C & & \\
DI Grow & $12,57 \mathrm{a}$ & $63,00 \mathrm{a}$ \\
GDM & $12,38 \mathrm{a}$ & $98,00 \mathrm{~b}$ \\
Growmore & $10,42 \mathrm{~b}$ & $98,33 \mathrm{~b}$ \\
\hline Media Tanam & & \\
& & \\
Top Soil & $11,90 \mathrm{p}$ & $90,15 \mathrm{p}$ \\
Arang Sekam & $12,05 \mathrm{p}$ & $91,07 \mathrm{p}$ \\
Humus daun & $11,95 \mathrm{q}$ & $90,80 \mathrm{p}$ \\
bambu & & \\
Pakis & $12,20 \mathrm{q}$ & $90,74 \mathrm{p}$ \\
\hline Interaksi & $(-)$ & $(-)$
\end{tabular}

Keterangan : Angka diikuti huruf sama menunjukkan tidak berbeda nyata pada uji, Duncan 5\%.

Tanda $(+)$ menunjukkan ada interaksi antar perlakuan.

\section{KESIMPULAN}

- Perlakuan pupuk organik DI Grow dan media tanam arang sekam menunjukkan hasil tertinggi secara nyata terhadap semua parameter pengamatan yaitu tinggi tanaman, luas daun, saat munculnya bunga, diameter bunga, diameter umbi dan umur panen.

- Perlakuan pupuk Growmore dan media tanam top soil menunjukkan hasil terendah secara nyata terhadap semua parameter pengamatan yaitu tinggi tanaman, luas daun, saat munculnya bunga, umur panen, diameter bunga dan umur pajang tanaman. 
Widiastuti \& Pamujiasih. 2019

- Tidak ada interaksi antara perlakuan macam media tanam dan macam pupuk organik cair pada semua parameter pengamatan.

\section{DAFTAR PUSTAKA}

Agustina, L. 2016. KajianManfaatUmbi dahlia (Dahlia pinnata) sebagaiprebiotik. LaporanPenelitianMandiri.

Campbell. 2012. Buku Ajar Biologi. Erlangga. Jakarta.

Gardner, F.P., R.B. Pearce, dan R.L. Mitchell. 1991. Fisiologi Tanaman Budidaya (Terjemahan oleh Herawati Susilo). UI Press. Jakarta.

Haryani, Y., S. Muthmainah, dan S. Sikumbang. 2013. Uji parameter non spesifik dan aktivitas antibakteri ekstrak methanol dari umbi tanaman dahlia (Dahliavariabilis). JurnalPenelitian Farmasi Indo. 1(2):43-46.

Iskandar, Y. M., S. Pudjiraharti, dan D. Ratnaningrum. 2014. Kandungan InulinDari Umbi Dahlia Sp Yang DitanamPadaJenis Tanah Vertisol, InceptisoldanAndisol. Jurnal Kimia Terapan Indonesia. 16 (1) : 25-31.

Prasetya, B. 2009.Pengaruh Dosis danFrekuensi Pupuk Cair TerhadapSerapan N Dan Pertumbuhan Sawi (Brassica junceaL.)Pada Entisol. Fakultas Pertanian. Universitas Brawijaya. Malang.JurnalAgronomi.17 (5).

Setyamidjaja, D. 1986. Pupuk dan Pemupukan. CV Simplex. Jakarta. 122 Halaman.

Suryadi, A.E. 2007. Ekstraksi dari Uji Aktivitas Antimikroba Ekstrak UmbiDahlia (Dahlia variabilis). Skripsi. FMIPA Universitas Riau. Pekanbaru.

Sutedjo, M. M,. 2010. Pupukdan Cara Pemupukan. RinekaCipta. Jakarta. 